\title{
Qualitative Assessment of Soils Based on Hydrophysical Parameters
}

\author{
${ }^{1}$ Valentina V. Khusnutdinova, ${ }^{2}$ Vyacheslav V. Sirotkin, ${ }^{3}$ Sergey V. Vasyukov, ${ }^{4}$ Bulat M. Usmanov \\ ${ }_{1,2,4}$ Institute of Environmental Sciences, Kazan Federal University, 18, Kremlevskaya str., 420008, Kazan, Russia \\ ${ }^{3}$ Federal Service for State Registration, Cadastre and Cartography, 56, Karl Marx str., 428003, Cheboksary, Russia \\ Email: Sirotkin67@rambler.ru
}

Received: $20^{\text {th }}$ August 2019, Accepted: $3^{\text {th }}$ September 2019, Published: $31^{\text {st }}$ October 2019

\begin{abstract}
A qualitative assessment of the main types of zonal soils is necessary to assess the potential fertility of agricultural land. Soil bonitet analysis is used for cost-effective agriculture, determining the resource potential of agricultural land. Despite the many works devoted to soil evaluation, the definition of objective criteria and soil rating scales have not been fully developed. In this paper it is proposed to use hydrophysical indicators of the main zonal soils of European Russia for a qualitative assessment of the soil cover of agricultural lands. As an example of the use of hydrophysical parameters for the qualitative assessment of soils, the soil evaluated in the municipal regions of the Chuvash Republic. The work used data obtained directly during field studies in selected key areas. As a result of the research, a table of the hydrophysical properties of automorphic soils was compiled, a multivariate correlation between hydrophysical indicators of the main automorphic soils and the humus content was made, as well as soil-geoecological zoning of the study area (six main types of soil-geoecological regions of the Chuvash Republic were identified). A scale of anthropogenic load on the soil was also developed. The difference between ball-bonitet of the entire soil cover and agrogenic soil proposed to use as a criterion of anthropogenic load on the soil cover.
\end{abstract}

\section{Keywords}

Hydrophysical Parameters, Soil Bonitet, Anthropogenic Load, Crop Productivity, Soil, Correlation Relationship

\section{Introduction}

Soil quality and land valuation issues are closely related to their rational use. This axiom is recognized not only by most scientists, but also in legislation., two chapters are devoted to land valuation, land monitoring, and the state land cadastre in the Land Code of the Russian Federation. The main methods for the qualitative soil cover assessment (bonitation), use the principles formulated by such outstanding scientists as V.V. Dokuchaev and N. M. Sibirtsev. In soils assessment, quantitative indicators of soil properties and agroclimatic conditions are also used, which are closely correlated with crop yields, with a similar level of agricultural intensity.

As the soils properties that correlate with long-term average productivity, humus, acidity, granulometric composition, absorption capacity, density, and thickness of the humus horizon are usually used.Therefore, in the methodology used by N.F.Tyumentsev [1], the soil properties basic initial data are volume weight $\left(\mathrm{g} / \mathrm{cm}^{3}\right)$, average humus content and mechanical fractions larger and smaller than $0.01 \mathrm{~mm}$ (in percent). In addition, he used data on reserves of gross nitrogen and phosphorus in soil horizons and information on other nutrients and soil properties. The agroclimatic indicators used for soil bonitet include, as a rule, the sum of active air temperatures (above $10^{\circ} \mathrm{C}$ ), the moistening coefficient (according to Vysotsky-Ivanov) and the continental climate degree.A close correlation between the properties of soils and long-term productivity is observed only within certain ecological and genetic series of soils (zonal series, bogging series, etc.), and clearly not defined for all the soils of the region.

Data on soil properties and crop yields are mathematically processed. The materials necessary to build soil evaluation scales can be processed in three ways:

1. This method is used by F.Y. Gavrilyuk, N. F. Tyumentsev. Two soil bonitet scales are being built, one - on the soils properties that correlate with productivity, and the second - based on crop productivity. The first is used as the main one, the second as a control.

2. V.D. Shuvalov method. A single scale is constructed simultaneously by the soils properties and by productivity, the average bonitet of the main soil groups are determined by productivity, and the specific soils bonitet within these groups are determined by soil properties, taking into account the general bonitet of the group.

3. Soil productivity method. Bonitets are calculated by productivity, soil properties are used to check the scales and refine the classification and soils grouping.

Most known are the bonitet scales developed by N.L. Blagovidov, F.Y. Gavrilyuk and N.F. Tyumentsev [1, 2]. In our opinion, hydrophysical indicators are the most informative characteristic of soils, allowing differentiating them by the presence of moisture for plants from an energy point of view [3, 4].There are a large number of soil assessment methods, where the humus content is taken as the main genetic property, at the same time there are no methods using hydrophysical indicators. Exceptions are the assessment by particle-size and the useof additional indicators such as volumetric weight of the soil and content of fractions less or more than 0,01 mm (Tyumentsev, 1982) [2].The ratio of the pressure equivalent to the moisture potential and the volumetric moisture content in soils with different specific surfaces and porosity values [5] can be used to solve many problems of soil quality studying and adjusting their parameters for optimal use, primarily for agricultural purposes. Due to the high spatial differentiation of soils 
hydrophysical parameters, reliable results should be based on the results of quantitative-qualitative stationary field studies.

\section{Methods}

To assess the quality of soils by hydrophysical parameters, we used the natural-historical method of soil bonitation (100 point system), developed by V.V. Dokuchaev and N.M. Sibirtsev (1984) [1] and methodological developments of N.F. Tyumentsev (1975) [2]. Soil evaluation was carried out according to the fourth category (classification by N. F. Tyumentsev), using the medium-scale soil map of the Chuvash Republic (1:300 000) and data on areas of soils, with their refinement on large-scale soil maps (1:50 000) and cropland soils area data.

The use of hydrophysical indicators for soil assessment was carried out for the first time [6], therefore, at the first stage, we compiled a table of hydrophysical characteristics of automorphic soils of the Chuvash Republic (Table 1), which also includes data on the humus content in the humus-accumulative (ploughed) layer. The table is based on the Chuvash Republic soils classification by professor S. I. Andreev (1971) [7]. In addition, data from field studies [8] were used, which were then compared with archive materials and literature sources $[9,10]$.

\begin{tabular}{|c|c|c|c|c|c|c|}
\hline Soil & $\begin{array}{c}\text { Volume } \\
\text { weight, } \\
\mathrm{g} / \mathrm{cm}^{3}\end{array}$ & $\begin{array}{c}\text { Particle } \\
\text { density, } \\
\mathrm{g} / \mathrm{cm}^{3}\end{array}$ & Porosity & $\begin{array}{c}\text { Specific } \\
\text { surface area, } \\
\mathrm{M}^{2} / \mathrm{M}^{3}\end{array}$ & $\begin{array}{c}\text { Water } \\
\text { conductivity, } \mathrm{m} / \mathrm{s}\end{array}$ & $\begin{array}{c}\text { Humus content } \\
\text { in the } 0-20 \mathrm{sm} \\
\text { layer, } \%\end{array}$ \\
\hline $\begin{array}{c}\text { Podzolic and sod strongly } \\
\text { podzolic }\end{array}$ & 1,6 & $2,64-2,61$ & 0,51 & 51,0 & $0,44 \cdot 10^{-5}$ & 1,48 \\
\hline Sod medium podzolic & 1,5 & $2,54-2,55$ & 0,52 & 79,5 & $0,011 \cdot 10^{-5}$ & 1,65 \\
\hline Sod weakly podzolic & 1,32 & $2,54-2,55$ & 0,56 & 98,1 & $1,65 \cdot 10^{-5}$ & 1,93 \\
\hline Light grey forest & $1,09-1,24$ & $2,61-2,59$ & $0,58-0,52$ & $119,2-138,1$ & $2,28 \cdot 10^{-5}$ & 3,08 \\
\hline Typical grey forest & $1,08-1,18$ & $2,59-2,57$ & $0,58-0,54$ & $138,1-162,4$ & $5,98-9,08 \cdot 10^{-5}$ & 3,62 \\
\hline Dark grey forest & $1,04-1,12$ & $2.54-2,48$ & $0,59-0,55$ & $162,4-183,6$ & $2,0-4,82 \cdot 10^{-5}$ & 5,54 \\
\hline Podzolic chernozem & $1,08-1,23$ & $2,20-2,27$ & 0,55 & $199,1-238,5$ & $1,45 \cdot 10^{-5}$ & 7,01 \\
\hline Leached chernozem & $0,99-1,21$ & $2,20-2,40$ & 0,58 & $238,5-257,8$ & $0,3-0,5 \cdot 10^{-5}$ & 8,2 \\
\hline Typical chernozem & 1,11 & 2,62 & 0,63 & 279,6 & $0,13 \cdot 10^{-5}$ & 8,6 \\
\hline
\end{tabular}

Table 1: Hydrophysical Properties of Automorphic Soils of the Chuvash Republic

At the next stage, a multivariate correlation was carried out between the hydrophysical indices of the main automorphic soils of the Chuvash Republic and the humus content in humus-accumulated layer. Correlation analysis is necessary in order to confirm the correct choice of hydrophysical criteria for bonitation (Table 2). The relationship of the humus content with all hydrophysical indicators and the relationship between all hydrophysical indicators are statistically significant with a probability of $0.95(\alpha=0.05)$.

Bonitet score calculated by the formula:

$\mathrm{B}=\mathrm{V}_{\mathrm{a}} / \mathrm{V}_{\mathrm{m}} * 10$

Bonitet score by the volumetric weight calculated by the formula:

$B=\left\{\begin{array}{l}(V m / V f) * 100, \text { if } V f>V m . \\ V f / V m * 100, \text { if } V f<V m .\end{array}\right.$

where $\mathrm{B}$ - is the soil bonitet score; $\mathrm{V}_{\mathrm{a}}$ - the actual value of any attribute (soil porosity, specific surface of soils); $\mathrm{V}_{\mathrm{m}}-$ is the maximum or optimal value for this attribute in case of complex dependencies, corresponding to its content in the soil, taken as 100 points.

The total score is obtained as the arithmetic mean between the soil properties scores. The Chuvash Republic automorphic soils bonitet scale is presented in Table 3.

\begin{tabular}{|c|c|c|c|c|c|c|}
\hline & $\begin{array}{c}\text { Volume weight, } \\
\mathrm{g} / \mathrm{cm}^{3}\end{array}$ & $\begin{array}{c}\text { Particle density, } \\
\mathrm{g} / \mathrm{cm}^{3}\end{array}$ & Porosity & \begin{tabular}{|c|} 
Specific \\
surface area, \\
$\mathrm{M}^{2} / \mathrm{M}^{3}$
\end{tabular} & \begin{tabular}{|c|} 
Water \\
conductivity, \\
$\mathrm{m} / \mathrm{s}$
\end{tabular} & $\begin{array}{c}\text { Humus content } \\
\text { in the } 0-20 \mathrm{sm} \\
\text { layer, } \%\end{array}$ \\
\hline $\begin{array}{l}\text { Volume weight, } \\
\mathrm{g} / \mathrm{cm}^{3}\end{array}$ & 1 & & & & & \\
\hline Particle density, $\mathrm{g} / \mathrm{cm}^{3}$ & 0,37 & 1 & & & & \\
\hline Porosity & $-0,76$ & $-0,06$ & 1 & & & \\
\hline $\begin{array}{c}\text { Specific } \\
\text { surface area, } \mathrm{M}^{2} / \mathrm{M}^{3}\end{array}$ & $-0,81$ & $-0,49$ & 0,86 & 1 & & \\
\hline Water conductivity, $\mathrm{m} / \mathrm{s}$ & $-0,40$ & 0,15 & 0,02 & $-0,06$ & 1 & \\
\hline $\begin{array}{l}\text { Humus content in the } 0-20 \\
\text { sm layer, } \%\end{array}$ & $-0,75$ & $-0,55$ & 0,79 & 0,98 & $-0,14$ & 1 \\
\hline
\end{tabular}

Table 2: Correlation Coefficients between the Humus Content and Soil Hydrophysical Characteristics 


\begin{tabular}{|c|c|c|c|c|c|c|c|}
\hline \multirow{2}{*}{ Soil } & \multicolumn{2}{|c|}{ Volume weight } & \multicolumn{2}{|c|}{ Porosity } & \multicolumn{2}{|c|}{$\begin{array}{c}\text { Specific } \\
\text { surface area }\end{array}$} & \multirow{2}{*}{$\begin{array}{c}\text { Total soil } \\
\text { Score }\end{array}$} \\
\hline & $\mathrm{g} / \mathrm{cm}^{3}$ & score & $\begin{array}{l}\text { percent- } \\
\text { tage }\end{array}$ & score & $\mathrm{M}^{2} / \mathrm{M}^{3}$ & score & \\
\hline $\begin{array}{l}\text { Podzolic and sod strongly } \\
\text { podzolic }\end{array}$ & 1,6 & 68 & 0,51 & 81 & 51,0 & 18 & 56 \\
\hline Sod medium podzolic & 1,5 & 72 & 0,52 & 83 & 79,5 & 28 & 61 \\
\hline Sod weakly podzolic & 1,32 & 82 & 0,56 & 89 & 98,1 & 35 & 69 \\
\hline Light grey forest & 1,17 & 92 & 0,55 & 87 & 128,7 & 46 & 75 \\
\hline Typical grey forest & 1,13 & 96 & 0,56 & 89 & 150,3 & 54 & 80 \\
\hline Podzolic chernozem & 1,16 & 93 & 0,55 & 87 & 218,8 & 78 & 86 \\
\hline Leached chernozem & 1,1 & 98 & 0,58 & 92 & 248,2 & 89 & 93 \\
\hline Typical chernozem & 1,11 & 97 & 0,63 & 100 & 279,6 & 100 & 99 \\
\hline
\end{tabular}

Table 3: Bonitet Scale for Automorphic Soils of the Chuvash Republic

\section{Results and Discussion}

Based on the obtained data bonitation of automorphic soils by the municipal districts of the Chuvash Republic was carried out. The total bonitet score is the multiplication of the specific soil area by bonitet score. The average bonitet score $\left(\mathrm{B}_{\mathrm{a}}\right)$ for all soils of the district is determined as the quotient of dividing the sum of these scores by the area of soils, the average bonitet score of agrogenic soils $\left(\mathrm{B}_{\mathrm{aa}}\right)$ is determined as the quotient of dividing the sum of agrogenicsoils scores by the total agrogenic soils area throughout the municipal district.

After determining the average bonitet scores for all soils(Fig. 1) and agrogenic soils(Fig. 2)for municipal districts, it is necessary to verify the bonitet by selected indicators. In most methods, the average multi-year yield of crops grown on this soil is taken as a control indicator. We used the average multi-year yield of grain and leguminous crops for five (1977-1980; 1997-2001) and twenty-year (1982-2001) periods as a control value.

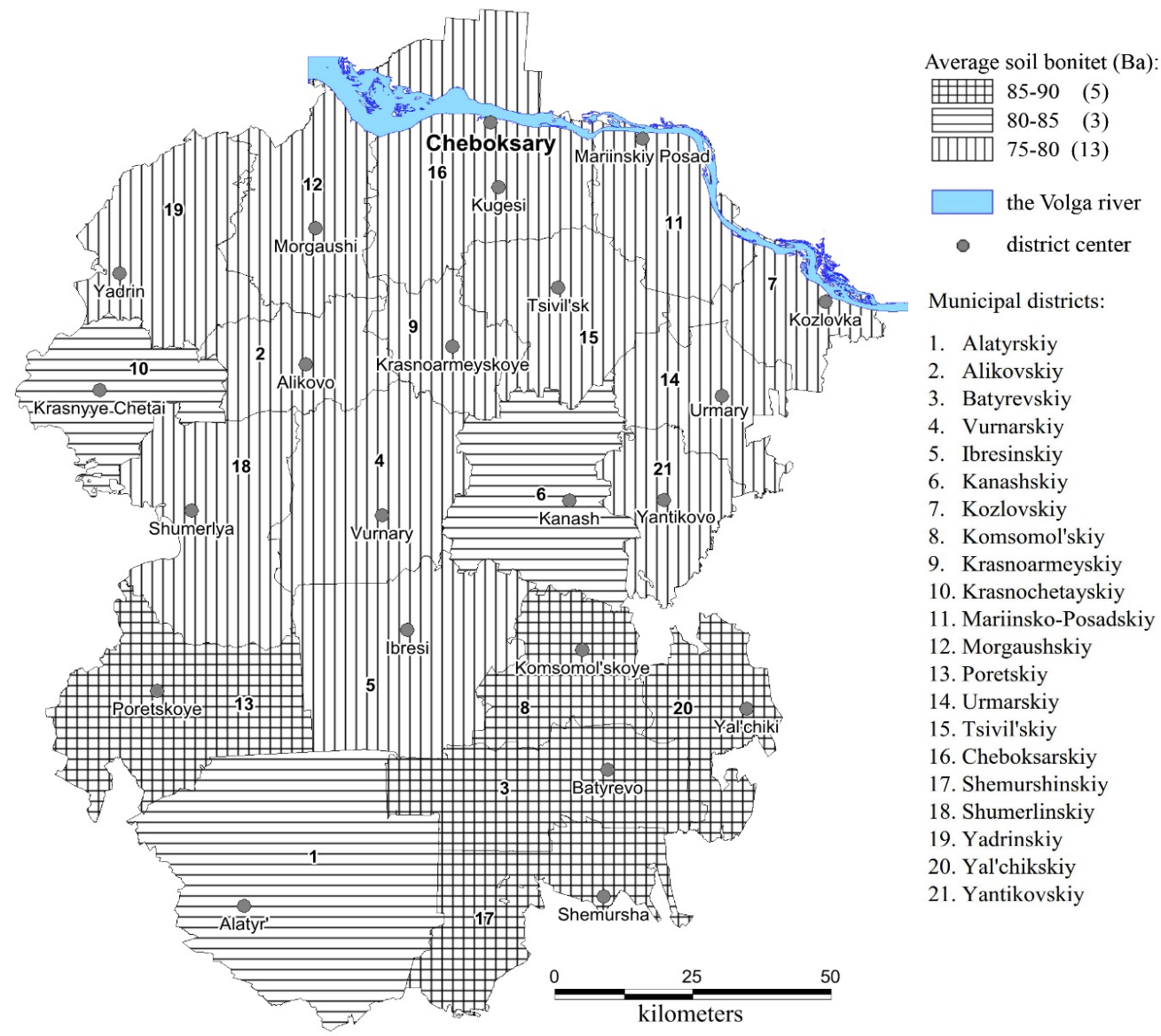

Fig. 1: Maps of Average Soil Bonitet for Chuvash Republic Municipal Districts 


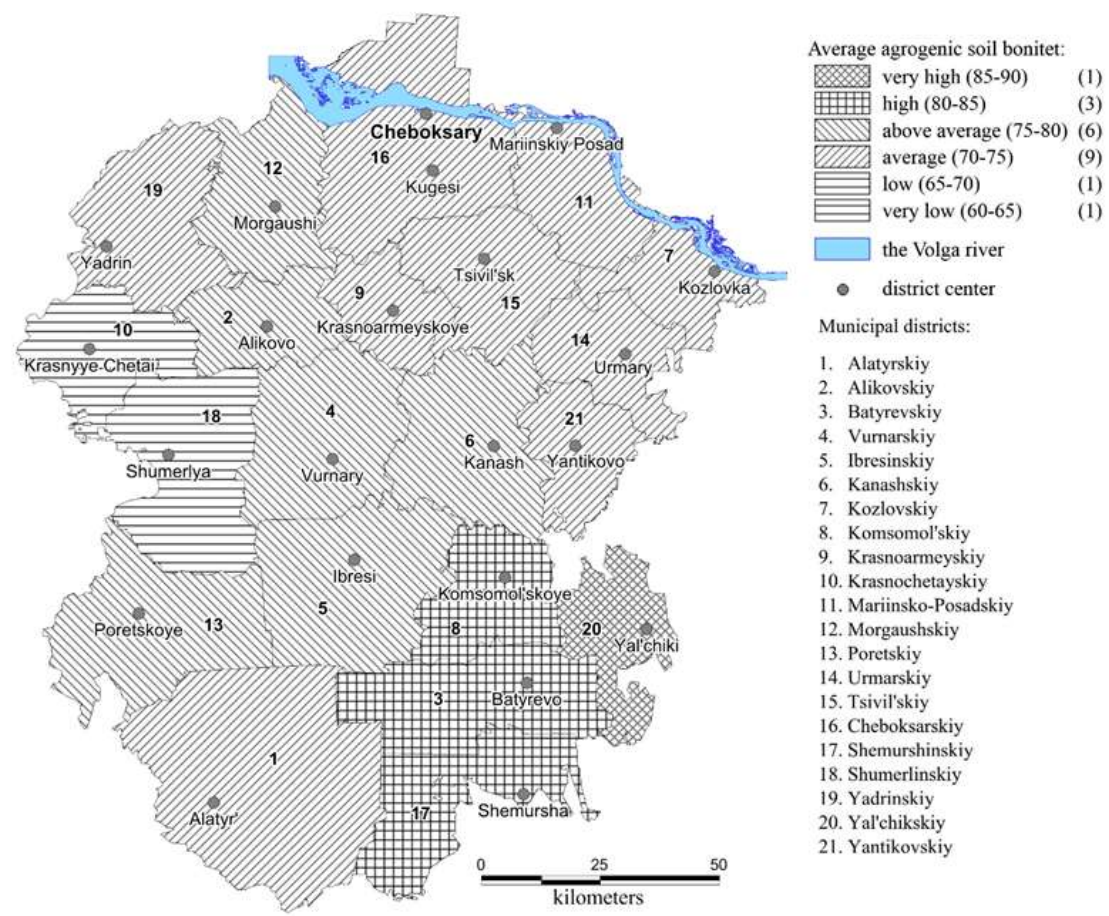

Fig. 2: Map of Average Agrogenic Soil Bonitet for Chuvash Republic Municipal Districts

Finally, we performed a correlation between the values $B_{a}, B_{a a}, D_{b}$, average yield of grain and leguminous crops for five (1977-1980; 1997-2001) and twenty-year (1982-2001) periods. The relationship between indicators is statistically significant with a probability of $0.95(\alpha=0.05)$. For convenience, all bonitet and yield indicators were displayed in cartographic form (Fig. 1, 2).

The $\mathrm{D}_{\mathrm{b}}$ index deserves a separate mention:

$D_{b}=B_{a}-B_{a a}$,

where $\mathrm{B}_{\mathrm{a}}$ - average bonitet score for all soils; $\mathrm{B}_{\mathrm{aa}}$-average bonitet score for agrogenicsoils; $\mathrm{D}_{b}$ - difference of bonitet. It shows automorphic soils involvement degree in the process of agricultural production. The higher is this indicator, the lower is the degree of automorphic soils use. It is reduced due to a more complete use of semi-hydromorphic and hydromorphic soils series, as less valuable for agriculture. The use of this indicator is able to solve the inverse problem - to indicate the degree of anthropogenic load on the soil, such as plowing. The lower it is, the correspondingly higher is the economic use of soils and, consequently, the anthropogenic load on them. Fig. 3 shows the distribution of $\mathrm{D}_{\mathrm{b}}$ trough municipal districts of the Chuvash Republic. Scale of anthropogenic load on the soil was developed (Table 4) on the base of $\mathrm{D}_{\mathrm{b}}$ indicator. 


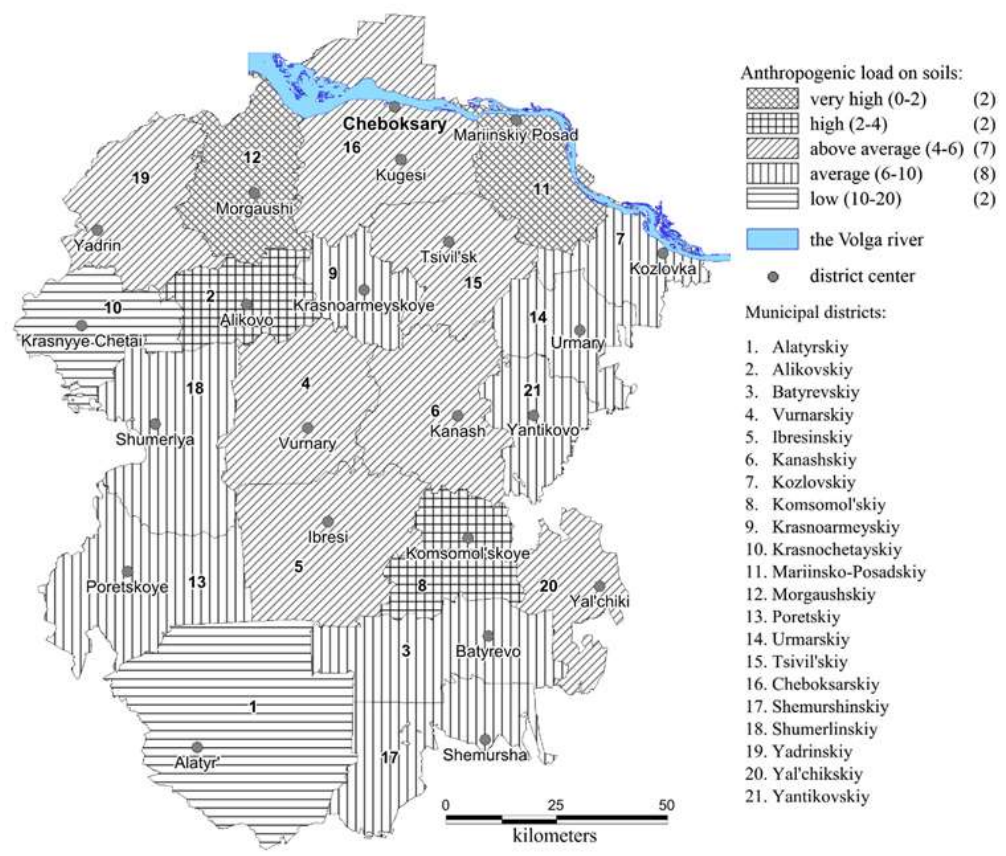

Fig. 3: Map of $D_{b}$ Indicator (Difference of Bonitet) for Chuvash Republic Municipal Districts

\begin{tabular}{|c|c|}
\hline Anthropogenic load & Difference of bonitets $\left(\mathrm{D}_{\mathrm{b}}\right)$ \\
\hline Low & $10-20$ \\
\hline Average & $6-10$ \\
\hline Above the average & $4-6$ \\
\hline High & $2-4$ \\
\hline Very high & $0-2$ \\
\hline
\end{tabular}

Table 4: Scale of Anthropogenic Load on the Chuvash Republic Soils

Based on the obtained indicators $\left(\mathrm{B}_{\mathrm{a}}, \mathrm{B}_{\mathrm{a}}, \mathrm{D}_{\mathrm{b}}\right)$ and cartographic material, soil-geoecological zoning of the Chuvash Republic territory was carried. Six main types of soil-geoecological regions were identified (Fig. 4, Table 5).

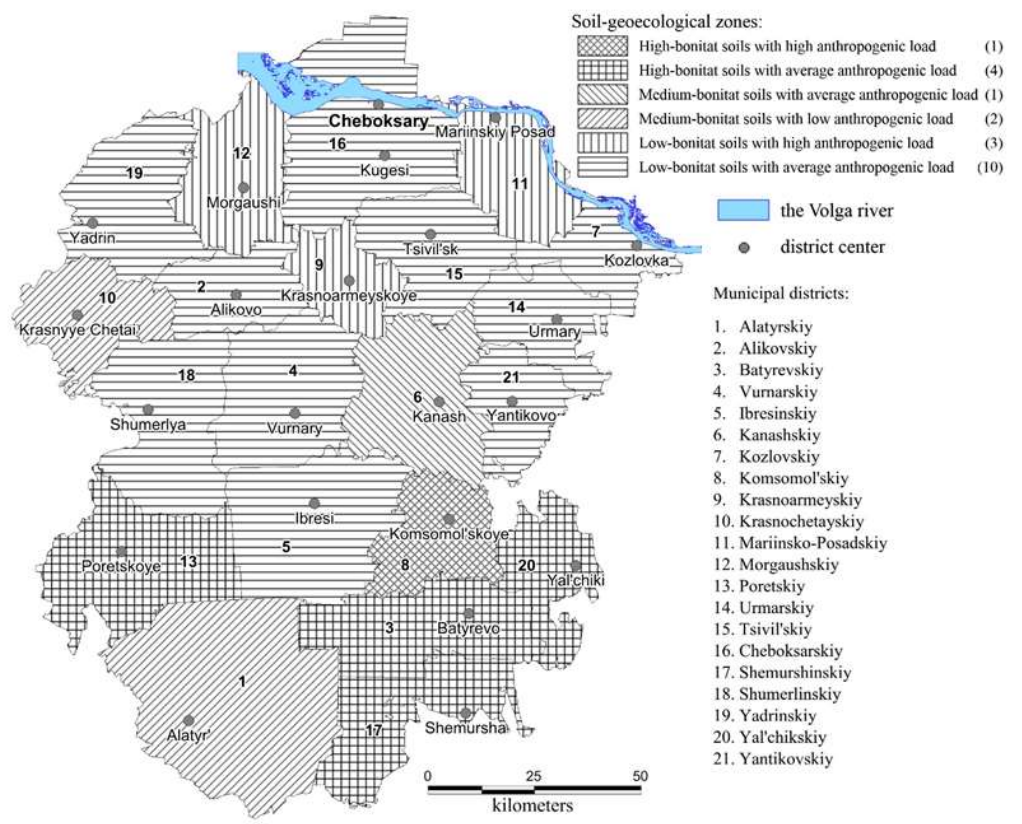

Fig. 4: Map of Soil-geoecological Zoning of the Chuvash Republic Territory 


\begin{tabular}{|c|c|c|c|c|}
\hline Rank & $\mathrm{B}_{\mathrm{a}}$ & $\mathrm{B}_{\mathrm{aa}}$ & $\mathrm{D}_{\mathrm{b}}$ & Municipal districts \\
\hline $\begin{array}{l}\text { High-bonitat soils with high } \\
\text { anthropogenic load }\end{array}$ & $>85$ & $>79$ & $0-4$ & Komsomol'skiy \\
\hline $\begin{array}{l}\text { High-bonitat soils with average } \\
\text { anthropogenic load }\end{array}$ & $>85$ & $>80$ & $4-10$ & $\begin{array}{c}\text { Batyrevskiy, Poretskiy, Shemurshinskiy, } \\
\text { Yal'chikskiy }\end{array}$ \\
\hline $\begin{array}{c}\begin{array}{c}\text { Medium-bonitat soils with average } \\
\text { anthropogenic load }\end{array} \\
\end{array}$ & $80-85$ & $70-80$ & $4-10$ & Kanashskiy \\
\hline $\begin{array}{l}\text { Medium-bonitat soils with low } \\
\text { anthropogenic load }\end{array}$ & $80-85$ & $70-80$ & $>10$ & Alatyrskiy, Krasnochetayskiy \\
\hline $\begin{array}{c}\text { Low-bonitat soils with high } \\
\text { anthropogenic load }\end{array}$ & $70-80$ & $60-70$ & $0-4$ & $\begin{array}{c}\text { Krasnoarmeyskiy, Mariinsko-Posadskiy, } \\
\text { Morgaushskiy }\end{array}$ \\
\hline $\begin{array}{l}\text { Low-bonitat soils with average } \\
\text { anthropogenic load }\end{array}$ & $70-80$ & $60-70$ & $6-10$ & $\begin{array}{c}\text { Alikovskiy, Vurnarskiy, Ibresinskiy, } \\
\text { Kozlovskiy, Urmarskiy, Tsivil'skiy, } \\
\text { Cheboksarskiy, Shumerlinskiy, Yadrinskiy, } \\
\text { Yantikovskiy }\end{array}$ \\
\hline
\end{tabular}

Table 5: Soil-geoecological Zoning of the Chuvash Republic

\section{Summary}

As a result of soils bonitation, we can make following conclusions:

- The $\mathrm{B}_{\mathrm{a}}$ indicator has a significant relationship with the $\mathrm{B}_{\mathrm{aa}}$, since both indicators express objective, qualitative soil properties, differing only in the calculation methodology and the number of areas taken into account. With all other indicators, including yield, $\mathrm{B}_{\mathrm{a}}$ has little connection. This is explained by the fact that this indicator estimates the entire soil cover of the territory, and not just agrogenicsoils. In addition, yield depends not only on objective soil indicators, but also on a number of anthropogenic factors (quantity and quality of fertilizers, crop rotation, agricultural activities, etc.).

- The $\mathrm{B}_{\mathrm{aa}}$ indicator has significant inverse correlation with the difference of bonitets $\left(\mathrm{D}_{\mathrm{b}}\right)$ and direct significant relationships with all yield indicators, which objectively proves the correctness of the selected criteria for bonitet evaluation. The most important is the significant relationship between $\mathrm{B}_{\mathrm{aa}}$ and average yield over a 20 -year period (1981-2001).

- The $\mathrm{D}_{\mathrm{b}}$ index has significant inverse correlation with the yield for a twenty-year period (1982-2001)due to its objective nature.

Analyzing the map of soil-geoecological zoning of Chuvash Republic territory (Fig.3), we can draw the following conclusions:

- Low-bonitat soils with a high anthropogenic load are most susceptible to degradation. There is a high degree of plowing of highly eroded soils in the territory of several municipal regions in the north of the republic (Table 5). In these territories, as a rule, sod-podzolic and light gray forest soils are widespread.

- High-bonitat soils with a high and medium anthropogenic load are degraded to a lesser extent. Arable land prevails in the south-east and south-west of the republic, but the soils of these territories are less prone to erosion. In these municipal regions (Table 5), prevail chernozems.

- Most of the municipal areas belong to the rank of low-bonitat soils with an average anthropogenic load. These are the territories of the central, northwestern and northeastern parts of the Chuvash Republic. Various subtypes of gray forest soils prevail in these areas.

- Alatyrskiy, Krasnochetayskiy municipal districts where prevail medium-bonitat soils with low anthropogenic pressure stands separate from the others with more forest areas and, accordingly, less agriculturallands. Chernozems, dark gray forest and sod-podzolic soils are common here.

\section{Conclusions}

For the first time it was proposed to use hydrophysical indicators (volume weight, particle density, porosity, specific surface area, water conductivity) for soil bonitet assessment. These parameters showed a very close correlation with humus content in the soil (the main bonitet feature in most modern soil assessment methods).Bonitation of automorphic soils of the Chuvash Republic by hydrophysical parameters was carried out. Bonitate scores were obtained for municipal areas for entire soil cover and for agrogenicsoils. As a criterion of anthropogenic load on the soil cover, as well as an indicator of a potential increase in soil fertility, the indicator $\mathrm{D}_{\mathrm{b}}$ was used (the difference between bonitet score for all soils and for agrogenic soils). The obtained bonitetindicators showed a significant relationship with the average long-term productivity of grain and leguminous crops in the municipal districts of the Chuvash Republic. As a result, soil-geoecological zoning of the Chuvash Republic territory was carried out, a set of maps and diagrams was created for all the main indicators. 


\section{Acknowledgements}

The work is performed according to the Russian Government Program of Competitive Growth of Kazan Federal University.

\section{References}

1. F.Y. Gavrilyuk,"Qualitative assessment of soil", Rostov: Rostov University Publishing House, 267 p., 1984.

2. N.F. Tyumentsev,"The essence of the soil bonitationon a genetic production basis", Novosibirsk, 134 p., 1975.

3. D.N.Jkimovich, V.V.Sirotkin, S.V.Vasyukov, "Experimental application of basic hydrophysical characteristic of soils in order to optimize their qualitative characteristics and agricultural soil quality evaluation criteria", RevistaPublicando,vol.4, is.13,pp. R214-PR226, 2017.

4. G.A. Larionov, O.G. Bushueva, N.G. Dobrovol'skaya, Z.P. Kiryukhina, S.F. Krasnov, L.F. Litvin, R.R. Murataev,"Determination of the hydrophysical parameters of soil in an erosion model",Eurasian Soil Science, vol. 43, is.4, pp. 453-458, 2010.

5. B. Ghanbarian, G.H. Allen, M.Sahimi, R.P. Ewing, T.E. Skinner,"Percolation Theory Generates a Physically Based Description of Tortuosity in Saturated and Unsaturated Porous Media",Soil Science Society of America Journal, vol. 77, is.6, 2013.

6. V.V. Sirotkin, I.M.Gasanov, "The latitude-zonal variability of hydrophysical and energy parameters of soils of the East and the South of European Part of Rus-sia", Research Journal of Pharmaceutical, Biological and Chemical Sciences,vol.7, is.5.pp.1508-1514, 2016.

7. S.I. Andreev,"Soils of the Chuvash ASSR",vol.1,"The history of the development of soil of the republic and their impact on humans",Cheboksary: Chuvash Book Publishing House, 358 p., 1971.

8. V.V.Sirotkin, S.V.Vasyukov, B.M.Usmanov,"Spectroscopic methods for determining of zonal soils erosion (Chuvash Republic, Russia)",IOP Conference Series: Earth and Environmental Science,vol.107, is.1, Art. № 012024, 2018.

9. A.M. Globus, "Experimental hydrophysics of soils", Gidrometeoizdat, 354 p., 1969.

10. A.D. Voronin, "Fundamentals of soil physics: work book",Moscow:Moscow University Publishing House, 286 p., 1986. 